\title{
PHOSPHATE SOLUBILIZATION POTENTIAL AND PHOSPHATASE ACTIVITY OF RHIZOSPHERIC TRICHODERMA SPP.
}

\author{
Anil Kapri; Lakshmi Tewari*
}

Department of Microbiology, G.B. Pant University of Agriculture \& Technology, Pantnagar-263145, Uttarakhand, India.

Submitted: April 30, 2009; Returned to authors for corrections: September 18, 2009; Approved: February 18, 2010.

\begin{abstract}
Trichoderma sp., a well known biological control agent against several phytopathogens, was tested for its phosphate $(\mathrm{P})$ solubilizing potential. Fourteen strains of Trichoderma sp. were isolated from the forest tree rhizospheres of pinus, deodar, bamboo, guava and oak on Trichoderma selective medium. The isolates were tested for their in-vitro P-solubilizing potential using National Botanical Research Institute Phosphate (NBRIP) broth containing tricalcium phosphate (TCP) as the sole P source, and compared with a standard culture of $T$. harzianum. All the cultures were found to solubilize TCP but with varying potential. The isolate DRT-1 showed maximum amount of soluble phosphate $\left(404.07 \mu \mathrm{g} \cdot \mathrm{ml}^{-1}\right)$, followed by the standard culture of $T$. harzianum $\left(386.42 \mu \mathrm{g} \cdot \mathrm{ml}^{-1}\right)$ after $96 \mathrm{~h}$ of incubation at $30 \pm 1^{0} \mathrm{C}$. Extra-cellular acid and alkaline phosphatases of the fungus were induced only in the presence of insoluble phosphorus source (TCP). High extra-cellular alkaline phosphatase activity was recorded for the isolate DRT-1 (14.50 U.ml $\left.{ }^{-1}\right)$ followed by the standard culture (13.41 U.ml ${ }^{-1}$ ) at $72 \mathrm{~h}$. The cultures showed much lesser acid phosphatase activities. Under glasshouse conditions, Trichoderma sp. inoculation increased chickpea (Cicer arietinum) growth parameters including shoot length, root length, fresh and dry weight of shoot as well as roots, in Pdeficient soil containing only bound phosphate (TCP). Shoot weight was increased by $23 \%$ and $33 \%$ by

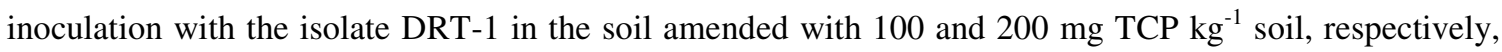
after $60 \mathrm{~d}$ of sowing. The study explores high P-solubilizing potential of Trichoderma sp., which can be exploited for the solubilization of fixed phosphates present in the soil, thereby enhancing soil fertility and plant growth.
\end{abstract}

Key words: Phosphate solubilization, Trichoderma, Acid phosphatase, Alkaline phosphatase, Chickpea.

\section{INTRODUCTION}

Phosphorus (P) is second only to Nitrogen $(\mathrm{N})$ as the most limiting element for plant growth $(3,18)$, making up about $0.2 \%$ of a plant's dry weight (25). The concentration of soluble $\mathrm{P}$ in soil ranges from 0.05 to $10 \mathrm{ppm}$ (4) and in soil, more than
$80 \%$ of $\mathrm{P}$ becomes immobile and unavailable for plant uptake because of adsorption, precipitation or conversion to organic form (12). The fixed form in alkaline soil is tri-calcium phosphate, $\mathrm{Ca}_{3}\left(\mathrm{PO}_{4}\right)_{2}$, while in acidic soil, it is mainly $\mathrm{FePO}_{4}$ and $\mathrm{AlPO}_{4}(26)$.

It has been observed by many investigators that a high

*Corresponding Author. Mailing address: Assistant Professor, Department of Microbiology, G.B. Pant University of Ag. \& Tech., Pantnagar-263145, India.; Tel: +91-5944-233341 (O) Fax: +91-5944-233341/233473.; E-mail: lakshmi_tewari@ yahoo.co.in 
proportion of $\mathrm{P}$ solubilizing microorganisms (PSMs) especially bacteria, fungi and actinomycetes reside in the rhizosphere of plants and play an important role in solubilization of bound phosphates, making them available to plants $(9,27,29)$.

Fungi have been reported to possess greater ability to solubilize rock-phosphate than bacteria (17). The fungi, and probably all living organisms, synthesize a number of phosphatases which are necessary to scavenge phosphates (Pi) from medium containing bound phosphorus. Both acid and alkaline phosphatases exist in soil and are distinguished on the basis of $\mathrm{pH}$ ranges at which they are active. These are secreted in response to signals of the absence of Pi (19). Seed or soil inoculation with PSMs is known to improve solubilization of fixed soil $\mathrm{P}$ and applied phosphates, resulting in higher crop yields $(1,7,14,23)$.

Considering the lower fertility level of soil, the study was primarily planned to evaluate the in-vitro phosphate solubilizing potential of rhizospheric Trichoderma spp. using National Botanical Research Institute Phosphate (NBRIP) medium and to investigate the induction of phosphatase (acid/alkaline) enzyme during the process in the culture medium. Based on these preliminary studies, superior isolates were selected for application in plant growth trials. The selected Trichoderma sp. isolates having high P-solubilizing potential were tested for influencing the growth of chickpea (Cicer arietinum) as a function of ' $\mathrm{P}$ ' application under glasshouse conditions.

\section{MATERIALS AND METHODS}

\section{Screening of Trichoderma spp. for in-vitro P-solubilization}

One standard culture of Trichoderma harzianum Rifai, MTCC792 (Th-Std) and fourteen isolates of Trichoderma spp. isolated from the forest tree rhizospheres of pinus (Pinus roxburghii: PRT-1, PRT-2, PRT-3), deodar (Cedrus deodara: DRT-1, DRT-2), bamboo (Bambusa bambos: BRP-2, BRH-2, BRH-3, BRH-4), guava (Psidium guajava: GRT-1, GRT-2), and oak (Quercus sp.: ORT-1, ORT-2 and ORT-4) were used in the present investigation. These cultures were taken from the departmental culture collection, Department of Microbiology, CBSH, G.B. Pant University of Agriculture and Technology, Pantnagar, India. The cultures were isolated on Trichoderma Selective Medium (TSM), grown on potato dextrose agar (PDA) at $28^{\circ} \mathrm{C}$ and maintained at $4^{0} \mathrm{C}$. The cultures were screened for their in-vitro phosphate solubilizing potential in NBRIP medium (18) which contained the following ingredients $\left(\mathrm{g} .1^{-1}\right)$ : glucose, 10.0; tricalcium phosphate (TCP), 10.0; $\mathrm{MgCl}_{2} .6 \quad \mathrm{H}_{2} \mathrm{O}, \quad 5.0 ; \mathrm{MgSO}_{4} .7 \mathrm{H}_{2} \mathrm{O}, 0.25 ; \mathrm{KCl}, 0.2 ;$ $\left(\mathrm{NH}_{4}\right)_{2} \mathrm{SO}_{4}, 0.1$.

Quantitative estimation of phosphate solubilization was carried out using Erlenmeyer flasks (100 ml) containing $45 \mathrm{ml}$ of medium inoculated in triplicate with four discs $(5 \mathrm{~mm}$ diameter) of active cultures of each Trichoderma sp. strain. Incubation was done at $28 \pm 1^{0} \mathrm{C}$ in an incubator shaker (Sanco, India) at $120 \mathrm{rpm}$ for $5 \mathrm{~d}$. An aliquot of $5 \mathrm{ml}$ was withdrawn periodically from each culture flask at $24 \mathrm{~h}$ interval. The samples were then centrifuged (Sigma, Germany) at 5,000 rpm for $10 \mathrm{~min}$ and supernatant of each culture was analyzed for $\mathrm{pH}$ ( $\mathrm{pH}$ meter, Systronics) and phosphate concentration. Phosphate in culture supernatant was estimated using the Fiske and Subbarow method (1925) (8), and expressed as equivalent phosphate $\left(\mu \mathrm{g} \cdot \mathrm{ml}^{-1}\right)$. The experiments were conducted in triplicates and values were expressed as their mean.

\section{Determination of Phosphatase enzyme activity}

Based on the P-solubilization studies, two isolates of Trichoderma sp. (DRT-1 and PRT-1) showing maximum Psolubilizing potential were selected for phosphatase enzyme induction studies using Pikovskaya's broth medium amended with three different combinations of bound phosphate (TCP) and available phosphates $\left(\mathrm{KH}_{2} \mathrm{PO}_{4}\right)$ : (1) TCP @ 10 g..$^{-1}$, but no $\mathrm{KH}_{2} \mathrm{PO}_{4}$; (2) TCP @ 10 g.l $\mathrm{l}^{-1}+\mathrm{KH}_{2} \mathrm{PO}_{4} @ 0.5$ g..$^{-1}$ and (3) $\mathrm{KH}_{2} \mathrm{PO}_{4} @ \mathrm{~g} . \mathrm{l}^{-1}$, but no TCP.

The supernatant (as obtained earlier) was used as crude enzyme extract for determining extracellular phosphatase enzyme activity spectrophotometrically (Beckmann DU, USA) at $405 \mathrm{~nm}$, using the method described by Lowry et al. (1951) (16). For determining specific activity, protein content in the 
culture filtrate was estimated according to the method described by Bradford (1976) (5) using Coomassie Brilliant Blue G-250 (CBBG-250). The experiment was conducted in triplicates and values were expressed as their mean.

\section{Soil characteristics and treatment}

A 1:1 mixture of soil:sand with available P-content as 8.44 kg P.ha ${ }^{-1}$ (P-deficient) was autoclaved at $121^{\circ} \mathrm{C}$ and $15 \mathrm{psi}$ for 15 min. This processed P-deficient soil was supplemented with three different levels of tricalcium phosphate (TCP) and two levels of single super-phosphate (SSP) as insoluble (bound) and soluble phosphate sources, respectively, in six different combinations as: $\mathrm{TCP}_{0}, \mathrm{SSP}_{0} ; \mathrm{TCP}_{0}, \mathrm{SSP}_{1} ; \mathrm{TCP}_{1}, \mathrm{SSP}_{0} ; \mathrm{TCP}_{1}$, $\mathrm{SSP}_{1} ; \mathrm{TCP}_{2}, \mathrm{SSP}_{0}$ and $\mathrm{TCP}_{2}, \mathrm{SSP}_{1}$, where $\mathrm{TCP}_{0}=$ no $\mathrm{TCP}$; $\mathrm{TCP}_{1}=100 \mathrm{mg} \cdot \mathrm{kg}^{-1}$ soil $\left(50.38 \mathrm{~kg} \mathrm{P}_{2} \mathrm{O}_{5} / \mathrm{ha}\right) ; \mathrm{TCP}_{2}=200$ mg.kg-1 soil (100.76 kg $\mathrm{P}_{2} \mathrm{O}_{5} \mathrm{ha}^{-1}$ ) (19); $\mathrm{SSP}_{0}=$ no SSP; $\mathrm{SSP}_{1}$ [recommended dose of SSP i.e. $165 \mathrm{mg} . \mathrm{kg}^{-1}$ soil $\left(60 \mathrm{~kg} \mathrm{P}_{2} \mathrm{O}_{5}\right.$ $\left.\left.\mathrm{ha}^{-1}\right)\right](20)$.

\section{Development of inoculum for glasshouse trial}

Th-Std and the isolate DRT-1 were inoculated on Roux bottles containing PDA and incubated for $5 \mathrm{~d}$ at $28 \pm 1^{0} \mathrm{C}$. The greenish spores were harvested aseptically using autoclaved water and spore-count $\left(\mathrm{cfu}^{-1} \mathrm{ml}^{-1}\right)$ was determined by serial dilution plate count method (6).

\section{Treatment of chickpea with Trichoderma isolates}

For pot-culture experiments, a late sown variety of chickpea (Cicer arietinum), Pant G-186 (Germination \% $83.3 \%, 100$ seed wt. -18.02 g, Maturation - 140 to $145 \mathrm{~d}$ ) was used. Trichoderma inoculation was done by two methods: (i) soil treatment and (ii) seed treatment. For soil treatment, $1 \mathrm{ml}$ of spore suspension of each culture containing $5.25 \times 10^{8}$ cfu.ml ${ }^{-1}$ (Th-Std) and $4.09 \times 10^{8}$ cfu.ml $^{-1}$ (DRT-1) was mixed thoroughly with soil in each pot. For seed treatment, carrierbased inoculum was prepared by mixing pre-sterilized talc powder (HiMedia, India) with the spore suspension of each culture in 1:1 (w/v) ratio. Surface-sterilized seeds (20 g) (sterilized using $0.1 \% \mathrm{HgCl}_{2}$ and $70 \%$ alcohol followed by thorough washing with sterile distilled water) were thoroughly mixed with the carrier based inoculum and left for $1 \mathrm{~h}$ before sowing.

A total of eighteen different treatments including six combinations of phosphate sources (TCP and SSP) and three levels of Trichoderma treatments $\left[\mathrm{T}_{0}\right.$ (no inoculation), Th-Std and DRT-1] with five replications of each were used for conducting the glasshouse studies on plant growth enhancement of chickpea. The values were expressed as their mean.

\section{Statistical analysis}

Completely randomized design (CRD) was followed for the designing of the experiments and the data was analyzed by ANOVA (analysis of variance). The common difference (CD) of the treatments was considered to be significant at the $5 \%$ level $(\mathrm{P}=0.05)$.

\section{RESULTS}

\section{Solubilization of bound phosphorus (TCP) by Trichoderma isolates}

All the cultures invariably showed very good mycelial growth in NBRIP broth, with simultaneous disappearance of TCP within $72 \mathrm{~h}$ in most of the cases. Concentration of solubilized phosphate gradually increased from 24 to $96 \mathrm{~h}$, and decreased thereafter (at $120 \mathrm{~h}$ ) invariably in the culture-filtrates of all the isolates (Table 1). Phosphate concentration varied from $111.5 \mu \mathrm{g} \cdot \mathrm{ml}^{-1}$ to $404.07 \mu \mathrm{g} \cdot \mathrm{ml}^{-1}$ in the culture filtrates of various Trichoderma cultures. Among all the cultures evaluated, the isolate DRT-1 showed significantly higher phosphate concentrations in the culture filtrate at all the time intervals as compared to the standard culture of T. harzianum and other isolates, while BRH-4 was the weakest P-solubilizer (Fig. 1A). Further, a gradual decrease in $\mathrm{pH}$ values was recorded in all the cases differentially. The $\mathrm{pH}$ values decreased to variable levels from neutral to those between 5.0 to 6.0 depending on the culture and later became nearly constant (Fig. 1b). The isolate DRT-1 showed maximum 
phosphate concentration $\left(\mu \mathrm{g} \cdot \mathrm{ml}^{-1}\right)$ of 404.07 at $96 \mathrm{~h}$, followed by Th-Std (386.42) and PRT-1(377.44) in the culture filtrate. Comparatively, a significantly lower phosphate concentrations were recorded in the culture filtrates of BRH-4 (300.06), ORT4 (303.22), ORT-1 (304.66) and GRT-1 (306.88) at $96 \mathrm{~h}$.

Table 1. Solubilization of Tricalcium phosphate $\left(10 \mathrm{~g} \mathrm{l}^{-1}\right)$ in NBRIP broth by various Trichoderma isolates

\begin{tabular}{|c|c|c|c|c|c|c|}
\hline \multirow[t]{2}{*}{ Isolates } & \multicolumn{5}{|c|}{ Concentration of solubilized phosphate $\left(\mu \mathrm{g} \cdot \mathrm{ml}^{-1}\right)$ at different time-intervals $(\mathrm{h})$} & \multirow{2}{*}{$\begin{array}{c}\text { \% P-solubilized w.r.t. } \\
\text { Th-Std after } 96 \mathrm{~h}\end{array}$} \\
\hline & 24 & 48 & 72 & 96 & 120 & \\
\hline Th-Std & 145.55 & 284.52 & 354.52 & 386.42 & 376.6 & 100.00 \\
\hline PRT-1 & 142.60 & 270.6 & 342.6 & 377.44 & 367.5 & 97.67 \\
\hline PRT-2 & 130.72 & 242.96 & 322.64 & 354.22 & 348.6 & 91.66 \\
\hline PRT-3 & 111.15 & 211.43 & 292.44 & 326.45 & 320.62 & 84.48 \\
\hline DRT-1 & 150.02 & 296.32 & 363.22 & 404.07 & 392.96 & 104.56 \\
\hline DRT-2 & 122.24 & 225.44 & 312.47 & 338.98 & 328.24 & 87.72 \\
\hline BRP-2 & 136.39 & 256.53 & 333.55 & 365.6 & 358.32 & 94.61 \\
\hline BRH-2 & 118.75 & 218.63 & 302.92 & 335.44 & 328.82 & 86.80 \\
\hline BRH-3 & 114.65 & 202.44 & 265.26 & 310.53 & 298.95 & 80.36 \\
\hline BRH-4 & 112.76 & 190.06 & 238.38 & 300.06 & 286.67 & 77.65 \\
\hline GRT-1 & 106.82 & 197.63 & 252.47 & 306.88 & 295.65 & 79.41 \\
\hline GRT-2 & 126.75 & 236.63 & 316.67 & 340.44 & 332.92 & 88.10 \\
\hline ORT-1 & 121.76 & 192.74 & 248.93 & 304.66 & 282.55 & 78.84 \\
\hline ORT-2 & 126.75 & 208.8 & 277.56 & 315.45 & 306.62 & 81.63 \\
\hline ORT-4 & 115.67 & 191.1 & 245.26 & 303.22 & 281.97 & 78.46 \\
\hline Control & 48.20 & 49.50 & 50.20 & 51.30 & 52.40 & - \\
\hline
\end{tabular}

$\mathrm{CD}(\mathrm{P}=0.05)$ : Isolate $(\mathrm{a})=6.64 ;$ Time interval $=3.83 ; \mathrm{a} * \mathrm{~b}=14.85$
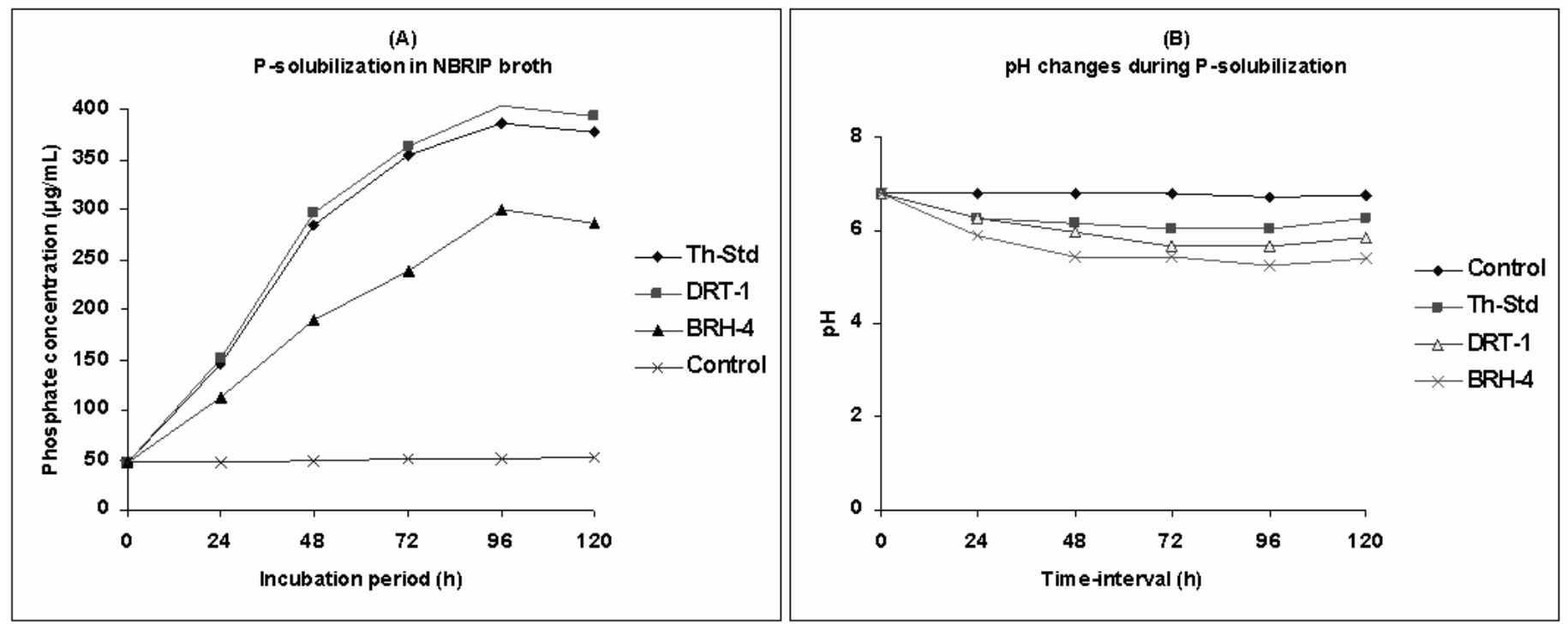

Figure 1. Concentration of phosphate solubilized (A) by Th-Std, DRT-1 \& BRH-4 along with pH changes (B) during incubation in NBRIP broth at different time intervals. 


\section{Extra cellular Acid phosphatase (AcP) enzyme activity}

AcP enzyme was induced by TCP $\left(10 \mathrm{~g} . \mathrm{l}^{-1}\right)$ in the PVK medium inoculated with Trichoderma sp. cultures as indicated by their enzyme activities (Fig. 2a). The activities reached maximum at $72 \mathrm{~h}$ interval for all the cultures and decreased upon further incubation at $96 \mathrm{~h}$. Maximum enzyme activity (2.33 U.ml ${ }^{-1}$ ) and specific activity (94.71 U.ml ${ }^{-1}$ ) were recorded by the standard culture of $T$. harzianum, which was significantly higher than the enzyme activity for other isolates. In the medium containing both available $\mathrm{P}, \mathrm{KH}_{2} \mathrm{PO}_{4}\left(0.5 \mathrm{~g} .1^{-1}\right)$ and bound P, TCP (10 g. $\left.\mathrm{l}^{-1}\right)$, a minimal enzyme activity was observed initially (at $48 \mathrm{~h}$ ) which gradually increased from 48 to $96 \mathrm{~h}$ (Table 2). The $\mathrm{TCP}_{0}$ treatment did not record any enzyme activity.

\section{Extra cellular Alkaline Phosphatase (ALP) enzyme activity}

Likely to AcPs, maximal extra cellular AlP activities were also recorded at $72 \mathrm{~h}$ interval invariably for all Trichoderma cultures in PVK media containing only bound phosphate i.e. TCP (10g. $\left.1^{-1}\right)$ (Fig. 2b). DRT-1 reported highest enzyme activity (14.50 U.ml ${ }^{-1}$ ) and specific activity (658.62 U.mg $\left.{ }^{-1}\right)$ at $72 \mathrm{~h}$ which was significantly higher than the activities recorded for Th-Std and PRT-1 cultures. In broth cultures amended with soluble phosphate at low concentration $\left(\mathrm{KH}_{2} \mathrm{PO}_{4} @ 0.5\right.$ g..$\left.^{-1}\right)$ along with TCP at high concentration (10 g. $\left.\mathrm{l}^{-1}\right)$, the cultures invariably showed a minimal activity during initial growth phase (at $48 \mathrm{~h}$ ) followed by a gradual increase, reaching maximum and significantly higher values at $96 \mathrm{~h}$ (Table 3). At
96 h, DRT-1 reported highest enzyme and specific activities followed by Th-Std and PRT-1 cultures. Moreover, no enzyme activity could be detected in the $\mathrm{TCP}_{0}$ treatment.

\section{Glasshouse experiment}

The influence of Trichoderma inoculation on chickpea was determined after $60 \mathrm{~d}$ of sowing by measuring different growth parameters viz. lengths of shoots and roots, along with their fresh and dry weights (Table 4). It was evident that growth of plants was not only enhanced in presence of available phosphorus (SSP) in comparison to plants growing in P-deficient soil, but it was also significantly stimulated by Trichoderma inoculation at both the levels of TCP viz. 100 and $200 \mathrm{mg} \cdot \mathrm{kg}^{-1}$ soil.

As compared to the treatments lacking any form of phosphorous source in the soil, a significant increase in all the growth parameters was observed in the presence of recommended dose of SSP i.e., $165 \mathrm{mg} . \mathrm{kg}^{-1}$ soil. With the further addition of Trichoderma cultures, a variable increase in the parameters was observed. However, when only TCP was provided as the phosphate source at a concentration of 100 mg.kg ${ }^{-1}$ soil, the chickpea plants recorded a significant increase in growth parameters which was comparable with the $\mathrm{SSP}_{1}$ treatments. Further, at a higher concentration of TCP i.e., 200 mg. $\mathrm{kg}^{-1}$ soil, a slight increase in all the parameters was observed. Furthermore, both the Trichoderma cultures (Th-Std and DRT-1) were more or less equally potential in enhancing the growth parameters of chickpea.

Table 2. Influence of different phosphorus sources on extracellular acid phosphatase enzyme activity of Trichoderma cultures grown in Pikovskaya's medium containing TCP and/or $\mathrm{KH}_{2} \mathrm{PO}_{4}$ at different time intervals

\begin{tabular}{|c|c|c|c|c|c|c|}
\hline \multirow{3}{*}{$\begin{array}{c}\text { Trichoderma } \\
\text { cultures }\end{array}$} & \multicolumn{6}{|c|}{ Acid phosphatase enzyme activity $\left(\mathrm{U} \mathrm{ml}^{-1}\right)$ of culture filtrates at different time intervals (h) } \\
\hline & \multicolumn{3}{|c|}{ TCP } & \multicolumn{3}{|c|}{$\mathbf{T C P}+\mathrm{KH}_{2} \mathrm{PO}_{4}$} \\
\hline & 48 & 72 & 96 & 48 & 72 & 96 \\
\hline Th-Std & 1.97 & 2.33 & 2.23 & 0.48 & 1.18 & 1.97 \\
\hline DRT-1 & 1.25 & 1.77 & 1.69 & 0.34 & 0.94 & 1.36 \\
\hline PRT-1 & 1.41 & 1.97 & 1.78 & 0.47 & 0.97 & 1.41 \\
\hline$C D$ at $5 \%$ & \multicolumn{3}{|c|}{$a=0.099 ; b=0.099 ; a * b=0.17$} & \multicolumn{3}{|c|}{$a=0.15 ; b=0.15 ; a * b=0.26$} \\
\hline
\end{tabular}



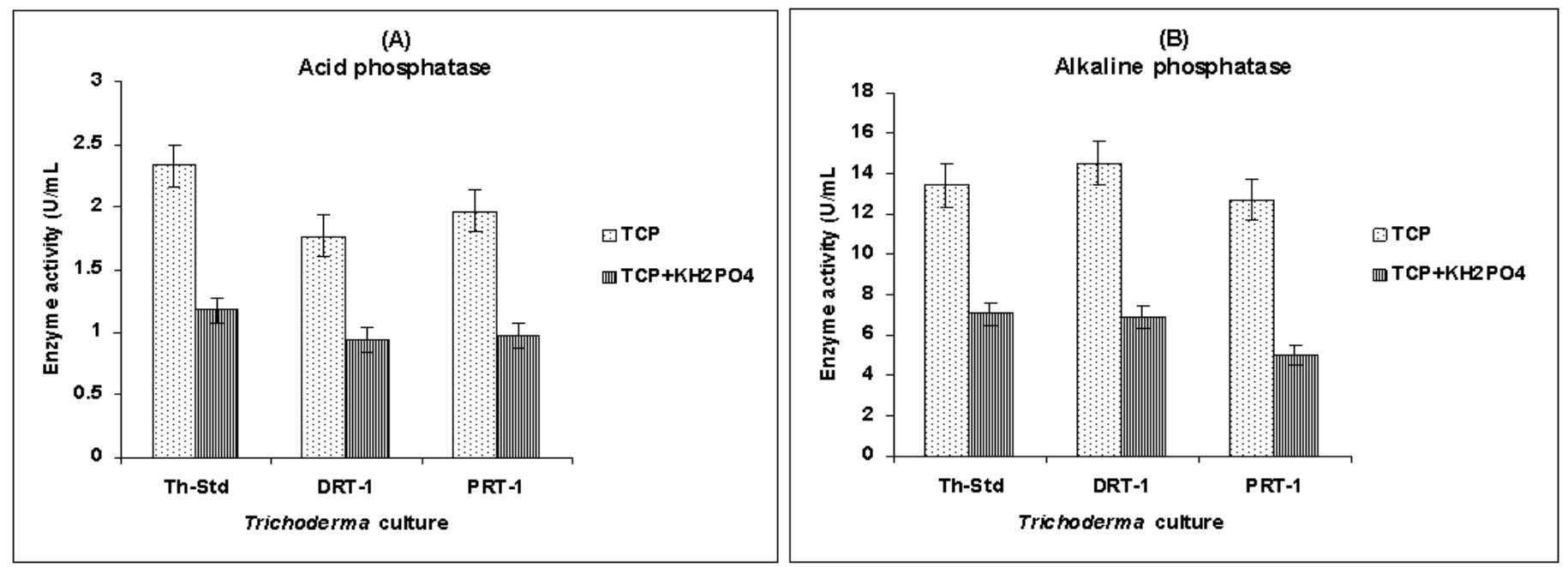

Figure 2. Comparative evaluation of Trichoderma cultures for induction of acid (A) and alkaline (B) phosphatase enzymes in the presence and absence of available phosphorus sources in Pikovskaya's medium at $72 \mathrm{~h}$.

Table 3. Influence of different phosphorus sources on extracellular alkaline phosphatase enzyme activity of Trichoderma cultures grown in Pikovskaya's medium containing TCP and/or $\mathrm{KH}_{2} \mathrm{PO}_{4}$ at different time intervals

\begin{tabular}{|c|c|c|c|c|c|c|}
\hline \multirow{3}{*}{$\begin{array}{c}\text { Trichoderma } \\
\text { cultures }\end{array}$} & \multicolumn{6}{|c|}{ Alkaline phosphatase enzyme activity $\left(\mathrm{U}_{\mathrm{mL}} \mathrm{mL}^{-1}\right)$ of culture filtrates at different time intervals $(\mathrm{h})$} \\
\hline & \multicolumn{3}{|c|}{ TCP } & \multicolumn{3}{|c|}{$\mathrm{TCP}+\mathrm{KH}_{2} \mathrm{PO}_{4}$} \\
\hline & 48 & 72 & 96 & 48 & 72 & 96 \\
\hline Th-Std & 12.50 & 13.41 & 12.75 & 2.58 & 7.08 & 9.66 \\
\hline DRT-1 & 14.16 & 14.50 & 14.41 & 2.66 & 6.91 & 13.50 \\
\hline PRT-1 & 11.83 & 12.69 & 12.41 & 1.83 & 5.00 & 9.16 \\
\hline$C D$ at $5 \%$ & \multicolumn{3}{|c|}{$\mathrm{a}=0.34 ; \mathrm{b}=0.34 ; \mathrm{a} * \mathrm{~b}=0.60$} & \multicolumn{3}{|c|}{$\mathrm{a}=0.29 ; \mathrm{b}=0.29 ; \mathrm{a}^{*} \mathrm{~b}=0.51$} \\
\hline
\end{tabular}

Table 4. Influence of Trichoderma inoculation on the growth of chickpea in the presence of different phosphorus sources* in Pdeficient soil under glasshouse conditions after $60 \mathrm{~d}$ of sowing

\begin{tabular}{cccccc}
\hline Phosphate source & Trichoderma treatment & $\begin{array}{c}\text { Shoot-length } \\
(\mathbf{c m})\end{array}$ & $\begin{array}{c}\text { Root-length } \\
(\mathbf{c m})\end{array}$ & \multicolumn{2}{c}{$\begin{array}{c}\text { Dry wt. (mg) } \\
\text { Shoot wt. }\end{array}$} \\
\hline Root wt. \\
\hline $\mathrm{TCP}_{0}, \mathrm{SSP}_{0}$ & NIL & 23.51 & 12.25 & 170.32 & 51.96 \\
& Th-Std & 23.82 & 13.60 & 171.25 & 52.88 \\
& DRT-1 & 23.29 & 13.20 & 165.18 & 53.06 \\
$\mathrm{TCP}_{0}, \mathrm{SSP}_{1}$ & NIL & 28.42 & 17.60 & 209.92 & 78.84 \\
& Th-Std & 29.83 & 17.50 & 214.94 & 78.44 \\
& DRT-1 & 28.22 & 17.10 & 198.03 & 76.26 \\
$\mathrm{TCP}_{1}, \mathrm{SSP}_{0}$ & NIL & 23.67 & 14.22 & 174.75 & 56.71 \\
& Th-Std & 29.46 & 17.10 & 213.53 & 76.02 \\
& DRT-1 & 29.25 & 16.82 & 215.66 & 75.78 \\
\hline
\end{tabular}




\begin{tabular}{cccccc}
\hline $\mathrm{TCP}_{1}, \mathrm{SSP}_{1}$ & NIL & 29.28 & 16.80 & 209.78 & 75.61 \\
& Th-Std & 31.22 & 17.81 & 216.45 & 82.15 \\
& DRT-1 & 30.24 & 17.16 & 221.56 & 78.88 \\
$\mathrm{TCP}_{2}, \mathrm{SSP}_{0}$ & $\mathrm{NIL}$ & 23.86 & 14.56 & 162.8 & 51.03 \\
& Th-Std & 30.61 & 18.25 & 216.02 & 83.04 \\
& DRT-1 & 31.20 & 17.83 & 217.84 & 79.66 \\
$\mathrm{TCP}_{2}, \mathrm{SSP}_{1}$ & NIL & 30.10 & 17.21 & 213.62 & 76.19 \\
& Th-Std & 32.94 & 18.46 & 235.72 & 84.48 \\
& DRT-1 & 33.34 & 18.05 & 236.24 & 85.20 \\
$C D$ at $5 \%$ & $a($ phosphate source) & 1.91 & 0.76 & 10.99 & 7.17 \\
& $b$ (Trichoderma treatment) & 1.35 & 0.54 & 7.77 & 5.07 \\
& $a * b$ & 3.31 & 1.32 & 19.04 & 12.41 \\
\hline$*$ TCP (tri-calcium phosphate), SSP (single superphosphate); Subscripts 0,1 and 2 for TCP indicate concentrations of 0,100 and $200 \mathrm{mg} \mathrm{kg}^{-1}$ soil,
\end{tabular}

respectively. Subscripts 0 and 1 for SSP indicate concentrations of 0 and $165 \mathrm{mg} \mathrm{kg}^{-1}$ soil, respectively.

\section{DISCUSSION}

\section{Phosphate solubilization by Trichoderma cultures}

Disappearance of TCP within $72 \mathrm{~h}$ indicates the high potential of Trichoderma for solubilization of inorganic bound phosphate (TCP), which might have been subsequently taken up by the fungus for cellular processes. All the rhizospheric isolates of Trichoderma showed variable phosphate solubilizing potential with Th-Std and DRT-1 being the best Psolubilizers (Table 1). Further, a gradual decrease in $\mathrm{pH}$ values is in agreement with the findings of Illmer and Schinner (1992) (13), who have also reported a decrease in $\mathrm{pH}$ upto four days followed by a gradual rise during P-solubilization by Penicillium and Pseudomonas in liquid cultures. It has been suggested that microorganisms which tend to decrease the $\mathrm{pH}$ of the medium during growth are efficient P-solubilizers (15). Contrary to the decreasing $\mathrm{pH}$ for individual cultures upto $48 \mathrm{~h}$ and then acquiring constancy, the soluble phosphate concentrations continue to increase after $48 \mathrm{~h}$. This clearly suggests that $\mathrm{pH}$ drop is not the sole factor for P-solubilization. An initial increase in phosphate concentration followed by a gradual decrease in culture filtrate as observed by us has also been well documented by other workers (18). Decrease in phosphate concentration at $120 \mathrm{~h}$ might be correlated with its sequestration in Trichoderma mycelium, to be released in a readily available form in close proximity to the roots after lysis of mycelium with age.

In the natural habitats, the phytopathogenic fungi like Pythium and Rhizoctonia are unable to solubilize phosphates and can be suppressed easily by the high competitive efficiency of $T$. harzianum through P-uptake (2). Apart from Psolubilization, simultaneous synthesis and release of pathogensuppressing metabolites like siderophores, phytohormones and lytic enzymes, by PSMs can prove to be useful (28).

\section{Extra cellular AcP enzyme activity}

The decrease in AcP activity of all the cultures after reaching a maximum at $72 \mathrm{~h}$ might be due to the repression of AcP by available phosphates released upon complete dissolution of TCP from the culture broths after $72 \mathrm{~h}$ interval. Enzyme activities in the range of 0.20 to 2.05 units have been reported in the case of Aspergillus caespitosus (10) while A. niger reported AcP specific activities of $64+8{\mathrm{U} . \mathrm{g}^{-1}}^{-1}$ and $99+11$ $\mathrm{U} . \mathrm{g}^{-1}$ at $\mathrm{pH} 6.3$ and 2.8 , respectively (11).

Further, in the medium containing both available $\mathrm{P}$, $\mathrm{KH}_{2} \mathrm{PO}_{4}\left(0.5 \mathrm{~g} . \mathrm{l}^{-1}\right)$ and bound P, TCP (10 g. $\left.\mathrm{l}^{-1}\right)$, a minimal enzyme activity was observed up to $48 \mathrm{~h}$. This is obviously due to the presence of readily available phosphate which represses AcP enzyme, as TCP solubilization is not needed. After the depletion of this small amount of $\mathrm{KH}_{2} \mathrm{PO}_{4}$, the phosphatase 
enzyme is induced again by TCP and hence activity increases from 48 to $96 \mathrm{~h}$. Th-Std showed superior enzyme activity (1.97 $\mathrm{U}^{\mathrm{ml}}{ }^{-1}$ ) and specific activity (93.80 U.mg ${ }^{-1}$ ) than other cultures. Further, in the medium containing only $\mathrm{KH}_{2} \mathrm{PO}_{4}\left(5 \mathrm{~g} . \mathrm{l}^{-1}\right)$ as the phosphorus source, no enzyme activity could be detected recorded, which clearly proves the need of an insoluble phosphate source (TCP) in the medium for the production of AcPs (19).

\section{Extra cellular ALP enzyme activity}

The high phosphatase activity of DRT-1 (14.50 U.ml $\left.{ }^{-1}\right)$ and specific activity (658.62 $\left.\mathrm{U}^{\mathrm{m} \mathrm{mg}^{-1}}\right)$ at $72 \mathrm{~h}$ would be responsible for its higher P-solubilizing potential in comparison to other cultures. The activities decreased slightly at $96 \mathrm{~h}$ interval, which might be due to the complete disappearance of TCP from the medium after $72 \mathrm{~h}$ of incubation. It is noteworthy that much higher ALP activities were recorded for Trichoderma sp. cultures than their AcP activities, which clearly indicates that the alkaline conditions are more favorable for the solubilization of phosphates. No ALP activity could be recorded by any of the cultures in broth containing higher concentration of available phosphate $\mathrm{KH}_{2} \mathrm{PO}_{4}\left(5{\mathrm{~g} . l^{-1}}^{-1}\right)$ as the sole phosphorus source, which again proved the need of an insoluble phosphate source for the secretion of phosphatases (19).

The above findings on phosphatase enzyme induction are in accordance with the P-solubilizing potential of the three cultures, proving DRT-1 and Th-Std as the best P-solubilizing potential Trichoderma sp.

\section{Glasshouse studies using chickpea}

About $22 \%$ and $33 \%$ increase in dry shoot weight, and about $35 \%$ and $60 \%$ increase in dry root weight was observed for $100 \mathrm{mg}$ and $200 \mathrm{mg}$ TCP application/kg soil respectively. However, significant difference between Th-Std and DRT-1 isolates with regards to growth parameters could not be well established, but both the isolates proved to be directly involved in promoting chickpea growth, probably by the dissolution of insoluble tri-calcium phosphate amended in the soil, as compared to uninoculated controls. Reyes et al., (2002) (22) reported phosphate solubilizing Penicillium to be able to stimulate the growth of maize plants as indicated by 3.6 to $28.6 \%$ increase in dry matter yields under greenhouse trials. Increase in growth and yield parameters of chickpea grown in P-deficient soil amended with insoluble rock phosphate due to Trichoderma inoculation, as compared to uninoculated controls under both glass house and field conditions has been reported by Rudresh et al, 2005 (23).

\section{CONCLUSION}

This study highlights the comparative phosphate solubilizing potential of Trichoderma sp. isolated from different tree rhizospheres. It was found that all the isolates were capable of differentially utilizing 10 g..$^{-1}$ TCP in NBRIP broth. This was indicated by the soluble phosphate concentrations $\left(\mu \mathrm{g} \cdot \mathrm{ml}^{-1}\right)$ and increase in acidity (decrease in $\mathrm{pH}$ ) of the growth medium. However, the P-solubilizing efficiency was found higher in case of the isolates, DRT-1 and Th-Std. This was further confirmed by their high AcP and ALP enzyme activities. Moreover, these isolates brought about significant increase in the growth parameters of chickpea under glasshouse trials, suggesting their applicability for crop improvement.

\section{REFERENCES}

1. Abd-Alla, M.H. (1994). Phosphates and the utilization of organic phosphorus by Rhizobium leguminosarum biovar. viceae. Lett. Appl. Microbiol. 18, 294-296.

2. Altomare, C.; Norvell, W.A.; Bjorkman, T.; Harman, G.E. (1999). Solubilization of phosphates \& micronutrients by the plant growth promoting \& biocontrol fungus Trichoderma harzianum Rifai 1295-22. Appl. Environ. Microbiol. 65, 2926-2933.

3. Beileski, R.L. (1973). Phosphate pools, phosphate transport and phosphate availability. Annu. Rev. Plant Phys. 24, 225-252.

4. Bhattacharya, P.; Jain, R.K. (2000). Phosphorus solubilizing biofertilizers in whirlpool of rock phosphate-challenges \& opportunities. Fertil. News 45(10), 45-72.

5. Bradford, M.M. (1976) A rapid and sensitive method for the quantification of microgram quantities of protein utilizing the principle of 
protein-dye binding. Anal. Biochem. 72, 248-254.

6. Cappuccino, J.G.; Sherman, N. (1996). Microbiology, A laboratory manual, $4^{\text {th }}$ Ed. The Benjamin/Cummings publishing company Inc. California.

7. El-Komy, H.M.A. (2005). Coimmobilization of Azospirillum lipoferum and Bcillus megaterium for successful phosphorus and nitrogen nutrition of wheat plants. Food Technol. Biotechnol. 43, 19-27.

8. Fiske, C.H.; Subbarow, Y. (1925). A colorimetric determination of phosphorus. J. Biol. Chem. 66, 375-400.

9. Gaur, A.C. (1990). Phosphate solubilizing Microorganisms as Biofertilizers. Omega Scientific publishers, New Delhi. pp. 176.

10. Guimaraes, L.H.; Terenzi, H.F.; Jorge, J.A.; Leone, F.A.; Polizeli, M.L. (2004). Characterization and properties of acid phosphatases with phytase activity produced by Aspergillus caespitosus. Biotechnol. Appl. Bioc. 40(2), 201-207.

11. Hidayat, B.J.; Eriksen, N.T.; Wiebe, M.G. (2006). Acid phosphatase production by Aspergillus niger N402A in continuous flow culture. FEMS Microbiol. Lett. 254, 324-331.

12. Holford, I.C.R. (1997). Soil phosphorus: its measurement, and its uptake by plants. Aust. J. Soil Res. 35, 227-239.

13. Illmer, P.; Schinner, F. (1992). Solubilization of inorganic phosphates by microorganisms isolated from forest soils. Soil Biol. Biochem. 24, 389395.

14. Illmer, P.; Barbato, A.; Schinner, F. (1995). Solubilization of hardlysoluble $\mathrm{AlPO}_{4}$ with P-solubilizing microorganisms. Soil Biol. Biochem. 27(3), 265-270.

15. Kpomblekou, A.K.; Tabatabai, M.A. (1994). Effect of organic acids on the release of phosphorus from phosphate rocks. Soil Sci. 158, 112-118.

16. Lowry, O.H.; Rosebrough, N.J.; Farr, A.L.; Randall, R.J. (1951). Protein measurement with the folin phenol reagent. J. Biol. Chem. 193:265-75.

17. Nahas, E. (1999). In: Inter-relacao fertilidale, biologia de solo e nutricae de plantas. Vicosa:SECS, Lairas: UFLA/DCS, pp. 467-468.

18. Nautiyal, C.S. (1999). An efficient microbiological growth medium for screening phosphorus solubilizing microorganisms. FEMS Microbiol. Lett. 170, 2017-2021.
19. Peleg. Y.; Addison, R.; Aramaya, R.; Metzenberg, R.L. (1996). Translocation of Neurospora crassa transcription factor NUC-1 into the nucleus is induced by phosphate limitation. Fungal Genet. Biol. 20, 185191.

20. Pillai, K.G.; Varmadevan, V.K. (1978). Studies on integrated nutrient supply system for rice. Fertil. News 23(3): 11-14.

21. Ratti, N.; Kumar, S.; Verma, H.N.; Gautam, S.P. (2001). Improvement in bioavailability of tricalcium phosphate to Cymbopogon mortii var. motia by rhizobacteria, AMF and Azospirillum inoculation. Microbiol. Res. 156(2), 145-149.

22. Reyes, I.; Bernier, L.; Antoun, H. (2002). Rock phosphate solubilization and colonization of maize rhizosphere by wild and genetically modified strains of Penicillium rugulosum. Microbial Ecol. 44(1), 39-48.

23. Rudresh, D.L.; Shivaprakash, M.K.; Prasad, R.D. (2005). Tricalcium phosphate solubilizing abilities of Trichoderma spp. In relation to Puptake \& growth yield parameters of chickpea (Cicer arietinum L.). Can. J. of Microbiol. 51, 217-226.

24. Sadasivam, S.; Manickam, A. (1998). Biochemical methods. $2^{\text {nd }}$ edition. New age international (p) Imt. Publishers and TamilNadu Agricultural University.

25. Schachtman, D.P.; Reid, R.J.; Ayling, S.M. (1998). Phosphate uptake by plants from soil to cell. Plant Physiol. 116, 447-453.

26. Subba Rao, N. S. (1999). In Soil Microbiology. Fourth Edition of Soil Microorganisms and Plant Growth. Oxford \& IBH Publishing Co. Pvt. Ltd., New Delhi.

27. Sujatha, S.; Sirisham, S.; Reddy, S.M. (2004). Phosphate solubilization by thermophilic microorganisms Indian J. Microbiol. 44(2), 101-104.

28. Vassilev, N.; Vasileva, M.A.; Nikolaeva, L. (2006). Simultaneous Psolubilizing and biocontrol activity of microorganisms: potentials and future trends. Appl. Microbiol. Biotechnol. 71(2), 137-144.

29. Vesquez, P.; Holiguin, G.; Puente, M.E.; Lopez Cortes, A.; Bashan, Y. (2000). Phosphate solubilizing microorganisms associated with the rhizosphere of mangroves in semi \& coastal lagoon. Biol. Fert. Soils. 460-468. 